\title{
GRIECO, FLORENCIA. EN COREA DEL NORTE: VIAJE A LA ÚLTIMA DINASTÍA COMUNISTA
}

Debate

2018. 256 pp.

\author{
Jungwon Park \\ Kyung Hee University
}

Es bien sabido que es difícil evitar la mirada orientalista para los ojos occidentales al escribir sobre Asia. Tal vez Corea del Norte es un caso excepcional porque llama mucho más la atención el aspecto ideológico y político. Este país todavía vive en la guerra fría contra el mundo capitalista. Encima de eso ha sido notoriamente conocido entre los países comunistas como el más aislado y cerrado por más de setenta años. Por un lado, es debido a las sanciones políticas y económicas del bloque occidental encabezado por los Estados Unidos. Por otro, el gobierno norcoreano mismo eligió no abrir la puerta en nombre de la defensa y la protección de su régimen de los ataques imperialistas. Como consecuencia, este país queda por antonomasia como el "reino ermitaño" que oculta misteriosamente los secretos de la última dinastía comunista. Al respecto, ¿qué implicaría un viaje a Corea del Norte? ¿La curiosidad por este país y el deseo de conocerlo refleja el interés en la ideología y el comunismo actual? ¿ $ं \mathrm{O}$ también contiene otro tipo de deseo orientalista?

En Corea del Norte: viaje a la última dinastía comunista es una crónica íntima, ensayo y diario de viaje a este país. Florencia Grieco, periodista argentina, revisitó Corea del Norte en 2017, después de su primer viaje en 2015, lo que corresponde a la temprana etapa del nuevo líder Kim Jong Un, tercer gobernante de la República Popular Democrática de Corea, a partir de 2011. Aunque no sean muchos, existen reportajes, testimonios y ensayos divulgados por periodistas internacionales, que muestran las realidades ocultadas detrás de la propaganda oficial, o entre los mitos construidos. Este libro sigue tal corriente, pero muestra un panorama muy reciente bajo el nuevo líder. La autora cuenta en primera persona sus experiencias personales con base en su segundo viaje.

El libro se divide básicamente en cuatro partes. La primera se enfoca en la preparación del viaje en Pekín antes de ingresar a Corea del Norte. Los procedimientos son anormales y el acceso es muy limitado; por ello, Grieco tuvo que buscar guías especiales que pudieran arreglar todos los trámites y llevarla a Pyongyang, la ciudad capital. La autora insinúa que el verdadero viaje empieza en China. La segunda parte se dedica a su estancia en Pyongyang. Grieco intenta ofrecer toda la información que puede adquirir bajo una condición limitada y, en particular, conocer a personas comunes, ajenas a la jerarquía del régimen. Pero no le queda otra opción que seguir el plan turístico cuya ruta ya está planeada por las autoridades norcoreanas. En lugar de seleccionar lugares preferidos se le obliga a visitar los espectáculos como las estatuas de veinte metros de altura de los líderes, la torre Juche, el hotel con más de cien pisos, etcétera. Grieco destaca este turismo oficialista que resulta "all inclusive [pero] que excluye el libre albedrío. Ni siquiera estaba permitida la holgazanería porque, a juicio de mis anfitriones, yo no estaba ahí de vacaciones" (p. 87). La tercera parte sale de la capital para conocer la famosa frontera con Corea del Sur, una de las más militarizadas del mundo. Grieco demuestra la triste realidad de división en que vive el pueblo coreano como dos ciudadanos distintos, como enemigos oficiales y como familias separadas. Fue el resultado del siglo pasado, pero ella enseña que la extrema 


\section{Grieco, Florencia. En Corea del Norte: Viaje a la última dinastía comunista \\ JUNGWON PARK}

vigilancia de esta frontera atestigua la continuación del odio, del temor y de la tensión entre las dos Coreas hasta ahora. El último destino de este libro es la región más interior, ubicada en el noreste del país. Mientras que Pyongyang es la ciudad privilegiada de la propaganda, esa región lejana no está diseñada para los turistas extranjeros. Allí Grieco puede ver fragmentos de la vida cotidiana ocultada detrás de la propaganda y el control social.

Lo que más se destaca en este libro, reside en la posición distinta de la autora gracias a su nacionalidad argentina. La lejanía no solamente geográfica sino también política, económica, psicológica y cultural entre la península coreana y Argentina le permite otro espacio narrativo: distanciamiento y balance. Diferente de los periodistas europeos y norteamericanos empapados de las imágenes estereotipadas, Grieco pretende mostrar otros aspectos de la sociedad norcoreana para evitar la sobregeneralización o la condena unidimensional. Por ejemplo, ella observa que la lógica de control total no solamente se percibe en el itinerario impuesto a los turistas, sino que también está imbuida en todo el sistema norcoreano. No obstante, no se limita a repetir la crítica de Occidente, que simplemente ridiculiza el régimen norcoreano en nombre del personalismo. Este libro va más allá eso: trata de mostrar escenarios raramente develados en los que se revelan otros puntos interpretativos. Grieco viaja al interior del país para extender su contacto con la gente común y corriente. En él, los norcoreanos curiosamente exhiben su interés por la autora totalmente desconocida que viene del otro extremo del globo. Además le expresan su disgusto por la visita etnográfica de los occidentales que no dejan de distorsionar las realidades norcoreanas. Este diálogo íntimo para ella ofreció "lo más cerca de 'la verdadera Corea' que jamás iba a estar" (p. 263).

La culminación de su viaje es cuando llega a la frontera confirmada después de los tres años de guerra civil. El libro intercala la escenificación de esta visita con la introducción histórica y política acerca de la formación de esta línea divisoria, como resultado de la colonización de la península coreana por el imperio japonés, la resistencia independentista, la ocupación de los países aliados después del fin de la Segunda Guerra Mundial, la división en las dos Coreas, el nacimiento de dos gobiernos (comunista y capitalista) y, finalmente, el estallido de la guerra. Grieco explica de manera breve pero efectiva la transformación del lado norcoreano: la heroización de su líder, la sucesión del poder a sus herederos, y la construcción de una dinastía militarmente organizada para defender su régimen de las amenazas del imperialismo occidental. Ella trata de ofrecer una perspectiva interna que nos permita entender cómo este país se ha convertido en el "reino ermitaño", y por qué motivo ha desarrollado armas nucleares. Si bien es conocido como uno de los "ejes del mal", lo que predomina en este país es una lógica de protección y defensa de su propio régimen.

Un aspecto impresionante de la autora es su profundo conocimiento acerca de la península coreana. Grieco entiende que los asuntos políticos y diplomáticos de Corea del Norte están innegablemente vinculados con el lado sur. En este sentido, ella — después de terminar este viaje — visita la misma frontera, pero esta vez desde el lado meridional. Aún en esta época tan globalizada no se permite cruzar esta línea divisoria. Corea del Sur forma una parte esencial de esta frontera anacrónica aunque está obteniendo una imagen futurista debido al desarrollo de tecnología. Frente a la frontera tan militarmente vigilada desde ambos lados, Grieco nos enseña que las dos Coreas están interconectadas y cada una es el doppelganger para la otra. Así se ha construido este sistema de división que ha durado por casi setenta años.

En suma, el viaje de Grieco no solo cuenta su experiencia personal, sino que ofrece un análisis general acerca de la sociedad norcoreana actual. En este sentido, el libro adquiere un valor mucho más significativo con respecto a la actual situación en que vive 
esta península. Los líderes de las dos Coreas se reunieron en 2018 con el objetivo de reabrir las conversaciones e iniciar la construcción de un sistema de cooperación. También, por primera vez, se realizó en Singapur la cumbre entre Kim Jong Un y Donald Trump para parar el programa nuclear de Corea del Norte. La negociación no es fácil, pero se encamina hacia el momento de poner un fin a la guerra y de establecer el acuerdo de paz. El siguiente paso será que Corea del Norte se abra al mundo. ¿Qué va a ocurrir en el futuro cercano? En esta drástica transición se requiere urgentemente una comprensión adecuada de este país ermitaño desde varios ángulos, no limitada al esquema dicotómico.

Indudablemente, este libro debe ser una nueva guía magistral. Para los latinoamericanos, Grieco puede ofrecer posibles respuestas a las preguntas o dudas que se han mantenido sobre Corea del Norte. Los lectores europeos y norteamericanos podrán conseguir otra perspectiva no alcanzada en los medios dominantes. Sobre todo, es un texto valioso para los surcoreanos que no saben muy bien de Corea del Norte porque hasta ahora no nos permiten visitarla. Es el momento para establecer una mejor relación con Corea del Norte a través de interacciones, comunicación y negociación. Siendo surcoreano, en este sentido, pienso personalmente que este libro debe ser traducido al coreano pronto. 